\title{
PROGRAM BEDAH RUMAH DENGAN MODEL PARTISIPATIF
}

\author{
Oleh: Muhammad Rusli, Tahrun Koko, Dewi Anggraini \\ 1,2,3 Program Studi Sosiologi FISIP Universitas Halu Oleo, Kendari
}

\begin{abstract}
Abstrak: Penelitian ini bertujuan mendeskripsi program bedah rumah dengan model partisipatoris, yakni mendiskripsi bentuk partisipasi masyarakat dan faktor-faktor yang mempengaruhi masyarakat terhadap Program Bedah Rumah. Penelitian kualitatif ini dengan informan dipilih secara purposive sampling. Melalui interview dan observasi sebagai alat utama pengumpulan data, penelitian ini menghasilkan beberapa temuan. Dengan model partisipatif, masyarakat desa ini secara maksimal mampu menyumbangkan pemikiran, tenaga, peralatan yang dimiliki untuk digunakan, dan bahan bangunan yang mereka miliki serta dana sesuai kemampuan masing-masing. Faktorfaktor yang mempengaruhi melakukan partisipasi tersebut terutama karena program ini diserahkan kepada mereka mengelola bersama sehingga mereka hampir tak kenal lelah menyumbangkan tenaganya dan yang memiliki peralatan apa saja mereka pinjamkan peralatannya untuk digunakan, sebagian berpartisipasi karena memiliki keterampilan pertukangan dan karena memiliki bahan bangunan. Kesempatan yang diberikan untuk terlibat dalam rangkaian program ini menjadi faktor utama dan menjadi social-energy untuk berpartisipasi dimana sekalipun telah membantu bekerja dan meminjamkan peralatan, mereka tetap menyumbang bahan bangunan yang dimiliki serta dana secara sukarela sesuai kemampuannya karena diberikannya kepercayaan dan kesempatan pengelolaan program untuk mereka sendiri. Faktor kemauan yang didasari nilai gotongroyong yang telah tertanam kuat pada masyarakat desa ini merupakan faktor yang juga cukup berpengaruh terhadap partisipasi masyarakat.
\end{abstract}

Kata Kunci: Model Partisipatif, Partisipasi Masyarakat, Program Bedah Rumah.

\section{PENDAHULUAN}

Hasil penelitian yang dilakukan oleh Asta Lugra Pramita dan kawankawan menunjukkan bahwa salah satu kelemahan utama dalam Program Bedah Rumah adalah tidak menjadikan masyarakat sebagai pelaku utama dalam pelaksanaan program tersebut (Pramita, 2015). Umumnya program bedah rumah dikelola oleh kepala desa (Nababan, 2018). Program bedah rumah yang dikelola oleh pihak pemerintah sebagaimana yang ditemukan Tondo bahwa tenaga kerja adalah pegawai negeri sipil yang tidak mempunyai keahlian atau keterampilan dan tidak demokratis (Tondo, 2017) sehingga rendahnya kualitas rumah tidak menjadikan masyarakat setempat menjadi pelaku utama tidak sesuai dengan program Bantuan Stimulan Perumahan Swadaya (BSPS) dari Kementerian Pekerjaan Umum dan Perumahan Rakyat
(PUPR) dimana berdasarkan Peraturan Menteri PUPR Nomor 07/PRT/M/2018, BSPS atau bedah rumah adalah bantuan pemerintah bagi masyarakat untuk mendorong dan meningkatkan keswadayaan dalam peningkatan kualitas rumah dan pembangunan baru rumah beserta prasarana, sarana, dan utilitas umum. Swadaya masyarakat diutamakan agar program ini mendorong dukungan atau partisipasi masyarakat dalam pemugaran rumah keluarga miskin (Pramita, 2014).

Partisipasi masyarakat Desa Poaroha dalam program bedah rumah diharapkan mempunyi manfaat efisiensi dan berbagai manfaat lainnya. Tenaga kerja dan keterampilan yang dimiliki masyarakat yang berpartisipasi tentu merupakan bentuk penghematan biaya. Partisipasi masyarakat untuk membangun rumah mereka, juga mempunyai efek sosial berupa terciptanya 
hubungan sosial yang lebih positif dan sebagai bentuk pelestarian sistem gotong royong. Nilai gotong royong atau nilai partisipasi masyarakat tentu bisa mengalami pergeseran oleh karena itu perlu mendeskripsi pelaksanaan program bedah rumah dengan model partisipatoris, yakni mendiskripsi bentuk partisipasi dan faktorfaktor yang mempengaruhi partisipasi masyarakat Poaraha.

\section{METODE PENELITIAN}

Penelitian ini dilakukan di Desa Poaroha Kecamatan Marobo Kabupaten Muna dengan pertimbangan pemilihan desa ini karena salah satu desa yang berhasil memenuhi target pelaksanaan program beda rumah.

Penelitian kualitatif ini mengambil sample dengan teknik purposive sampling dimana informan dipilih berdasarkan kriteria yang telah ditetapkan sesuai dengan tujuan penelitian, yakni pihak yang turut bertanggung jawab dalam program bedah rumah dalam hal ini Kepala Desa Poaraha, lima partisipan program, dua tokoh masyarakat/pemuda dan lima pemilik rumah yang dibedah. Data diperoleh melalui observasi partisipasi, wawancara, dan mendapatkan data dari dokumen. Dalam interview menggunakan pedoman wawancara yang telah disediakan dimana dalam pedoman meliputi bentuk partisipasi dan faktor-faktor yang mempengaruhi setiap bentuk partisipasi dan program bedah rumah.

Data yang diperoleh dari teknik ini dikumpulkan kemudian dilakukan reduksi data dengan cara membuat abstraksi (rangkuman inti) sehingga menjadi suatu informasi tentang bentuk partisipasi dan faktor yang mempengaruhi setiap partisipasi. Untuk meyakinkan validnya data dilakukan triangulasi dimana data dari informan diperoleh dalam waktu yang berbeda untuk mencocokkan kesesuaian data sebelumnya.

\section{PEMBAHASAN}

Partisipasi berarti peran serta, mengikuti dan menyertai pemerintah karena kenyataannya pemerintahlah yang dewasa ini perancang, penyelenggara dan pengawasan dari pembangunan tersebut. Menurut Made Pidarta dalam Siti Irene Astuti D. (2009), partisipasi adalah pelibatan seseorang atau beberapa orang dalam suatu kegiatan. Keterlibatan dapat berupa keterlibatan mental dan emosi serta fisik dalam menggunakan segala kemampuan yang dimilikinya (berinisiatif) dalam segala kegiatan yang dilaksanakan serta mendukung pencapaian tujuan dan tanggung jawab atas segala keterlibatan.

Menurut Syahyuti (2006), partisipasi adalah proses tumbuhnya kesadaran terhadap kesalinghubungan diantara stakeholders yang berbeda dalam masyarakat, yaitu antara kelompok-kelompok sosial dan komunitas dengan pengambil kebijakan dan lembaga-lembaga lain. Secara sederhana partisipasi dapat dimaknai sebagai "the act of taking part or sharing in something" (sikap atau tindakan mengambil bagian dalam sebuah kesempatan atau berbagi sesuatu).

Mikkelsen (1999), membagi partisipasi menjadi 6 (enam) pengertian, yaitu:

1. Partisipasi adalah kontribusi sukarela dari masyarakat kepada proyek tanpa ikut serta dalam pengambilan keputusan.

2. Partisipasi adalah "pemekaan" (membuat peka) pihak masyarakat untuk meningkatkan kemauan menerima dan keputusan untuk menggapai proyekproyek pembangunan.

3. Partisipasi adalah keterlibatan sukarela oleh masyarakat dalam perubahan yang ditentukannya sendiri.

4. Partisipasi adalah suatu proses yamg aktif yang mengandung arti bahwa orang atau kelompok yang terkait, mengambil inisiatif dan menggunakan kebebasannya untuk melakukan hal itu. 
5. Partisipasi adalah pemantapan dialog antar masyarakat setempat dengan para staf yang melakukan persiapan, pelaksanaan, monitoring proyek, agar supaya memperoleh informasi mengenai konteks lokal dan dampak-dampak sosial.

6. Partisipasi adalah keterlibatan masyarakat dalam pembangunan diri, kehidupan dan lingkungan mereka.

Menurut K. Davis dalam Sastropoetro (1998) bahwa bentuk partisipasi meliputi ide-ide/pikiran, tenaga, harta benda, dana/uang, dan keterampilan.

Bentuk-Bentuk Partisipasi Masyarakat dalam Program Bedah Rumah

\section{Partisipasi Masyarakat dalam Bentuk Buah Pikiran}

Musyawarah tahap persiapan program bedah rumah terutama bertujuan membicarakan siapa-siapa yang akan mendapat mendapat bantuan bedah rumah dan agar dalam pelaksanaan bedah rumah berjalann lancar. Peserta dalam musyawarah ini berhak menyampaikan usulan siapa yang layak mendapatkan bantuan bedah rumah dengan alasan-alasannya sehingga yang diajukan layak mendapat bantuan atau tepat sasaran. Dalam musyawarah yang dihadiri kepala desa juga dibicarakan dan diputuskan siapasiapa yang terlibat dan perannya dalam pelaksanaan bedah rumah agar perlaksanaannya berjalan lancar dan tercapai tujuan secara efisien dan efektif.

Perhatian masyarakat desa ini terhadap 'bedah rumah' atau renovasi rumah sangat tinggi sehingga menjadi perbincangan baik secara formal, seperti diskusi dalam musyawarah desa maupun perbincangan informal. Dalam perbincangan formal, masyarakat diwakili tokohtokoh masyarakat meliputi tokoh adat, tokoh agama, tokoh pemuda dan wanita. Mereka mewakili seluruh warga dan membawa ke dalam forum ini juga pandangan atau pemikiran warga yang diperoleh dari perbincangan informal.
Mereka umumnya antusias membicarakan program ini karena pentingnya renovasi rumah. Menurut mereka, perhatian pemerintah untuk merenovasi rumah yang tidak layak atau tidak sehat sangat tepat karena beberapa rumah yang tidak layak namun pemiliknya tak mampu merenovasi dengan biaya sendiri.

Partisipasi buah pikiran disampaikan melalui pertemuan atau rapat desa baik juga dalam rapat tahap pelaksanaan atau teknis, maupun evaluasi. Dalam rapat perencanaan, peserta rapat memberi pertimbangan dan kriteria rumah yang prioritas mendapat bantuan Program Bedah Rumah. Dalam rapat teknis pelaksanaan terutama mereka membicarakan dan menentukan yang bisa terlibat langsung dan perannya masingmasing dalam program tersebut sesuai kemampuan dan keterampilan yang dimiliki, misal tukang kayu, tukang batu, tukang cet dan peran lainnya, juga memberi informasi tempat memperoleh dan harga bahan yang diperlukan. Dalam rapat evaluasi mereka membicarakan pandangan tentang kekurangan, hambatan serta faktor yang menunjang pelaksanaan program.

Informasi atau pendapat dari warga ini dibutuhkan untuk mencegah salah sasaran dan dapat menjadi rumusan kriteria standar atau prasyarat dalam pengajuan usulan bantuan bedah rumah. Penilaian tingkat desa ini diperlukan di samping penilaian tingkat petugas yang akan menilai kelayakan kondisi tempat tinggal calon penerima bantuan bedah rumah yang diusulkan (Supriana, 2016).

Dengan pemberian pandangan dan masukan yang kemudian menghasilkan kesepakatan hasil musyawarah sehingga warga bisa menerima keputusan tersebut. Tidak sebagaimana di berbagai kasus karena penentuan rumah yang dibedah ditentukan sepihak, yakni pihak pemerintah desa sehingga kadang-kadang terjadi penyimpangan, misal tidak tepat sasaran, tidak tepat kualitas bangunan dan 
sebagainya. Dengan demikian bantuan pemikiran atau ide-ide ini menciptakan efisiensi, tepat sasaran, meminimalkan gejolak yang bisa muncul karena saling menyalahkan, memaksimalkan rasa tanggung jawab dan mendorong partisipasi atau melestarikan system gotong-royong serta semakin menguatkan integrasi atau toleransi sosial.

\section{Partisipasi Masyarakat dalam Bentuk Tenaga}

Kebiasaan gotong royong masyarakat mewarnai pula partisipasinya dalam Program Bedah Rumah. Dengan melibatkan mereka dalam program bedah rumah membuat masyarakat setempat ini dihargai dan menguatkan kebiasaan atau budaya gotong royong masyarakat desa ini.

Warga desa ini umumnya adalah pekerja keras karena setiap hari bekerja, seperti bekerja di kebun, pekerja bangunan dan sebagainya sehingga mereka mempunyai kemampuan tenaga yang cukup memadai untuk membantu dengan tenaga fisik. Jika dalam sehari tak bekerjamereka merasa tidak nyaman. Oleh karena itu bantuan tenaga yang mereka sumbangkan dianggap ringan.

Bantuan tenaga fisik dari masyarakat mulai dari pembongkaran rumah, pembangunan rumah, hingga pembersihan rumah dan sekitar atau pekarangan rumah. Sebelum rumah di renovasi harus dibongkar lebih dahulu terutama yang akan diganti, misal atap atau dinding rumah.

Pada saat pembongkaran ini sangat memerlukan tenaga fisik, baik untuk membongkar maupun untuk mengangkat bahanbahan bongkaran yang cukup berat. Jika tidak melibatkan masyarakat dalam pembongkaran ini sangatlah berat bagi pemilik atau pihak yang akan membangun rumah ini, terutama kalau bedah rumah hanya dilaksanakan oleh pihak aparat pemerintah desa.

Dalam pelaksanaan pembangunan atau renovasi, warga membantu dengan bekerja sesuai kemampuan dan peralatan yang digunakan. Warga yang tidak membawa atau tidak memegang peralatan hanya membantu apa saja yang bisa dikerjakan. Yang pasti bahwa mereka memberikan bantuan tenaga semampu mungkin untuk dapat mewujudkan rumah yang direncanakan untuk saudara mereka.

Semangat membantu dengan tenaga ini nampak seperti tak kenal lelah karena selain memiliki kemampuan tenaga fisik yang memadai juga bagian dari solidaritas untuk menguatkan integrasi mereka. Warga yang umumnya etnis Muna ini dikenal mempunyai tenaga fisik yang memadai, dikenal sebagai pekerja keras. Hanya saja walaupun memiliki kemampuan tenaga fisik kalau tidak sengaja dilibatkan maka tidak juga dapat berpartisipasi.

Mereka dengan semangat mengangkat bahan-bahan atau benda-benda yang diperlukan untuk pembangunan bedah rumah, mengangkat batu, mengangkat pasir, mengangkat semen, mengangkat kayu dan semua bahan lain yang diperlukan dalam proses pembangunan bedah rumah ini. Mereka mengangkat bahan-bahan itu tentunya tidak dilakukan sendiri melainkan secara bersama-sama sesama warga masyarakat. Dengan cara kerja bersama tersebut selain terasa ringan dalam bekerja juga menciptakan kerjasama dan toleransi.

Sumbangan tenaga yang mereka lakukan sebenarnya bukan hanya terjadi pada pelaksanaan program bedah rumah ini, akan tetapi partisipasi tenaga yang mereka berikan telah ada pada setiap program yang ada di desa tersebut, seperti pembangunan balai desa, pembangunan masjid, pembanguan lapangan, dan bahkan sampai pada program PNPM dan pengalokasian dana desa yang diluncurkan dalam bentuk bantuan WC di setiap rumah masyarakat.

Para ibu-ibu juga senantiasa ikut membantu sesuai kemampuannya, misalnya memasak untuk makan laki-laki yang bekerja dan membersihkan rumah yang 
mendapat bantuan program bedah rumah itu dan sekitarnya. Tenaga perempuan yang disumbangkan tidak seberapa tetapi dengan menyediakan makanan berarti turut memberi kontribusi bagi energy laki-laki untuk bekerja.

Bantuan tenaga warga, baik laki-laki maupun perempuan ini bukan saja mempunyai nilai efesiensi biaya bahkan juga memberi semangat kebersamaan yang memberi social-energy yang memberi semangat kerja dan kerja sama.

\section{Partisipasi Masyarakat dalam Bentuk Materi}

Masyarakat ini umumnnya tak segan membantu dalam bentuk materi atau peralatan yang dimiliki untuk dimanfaatkan dalam pembangunan atau renovasi warga. Kebiasaan warga memberikan apa saja yang dimiliki jika ada tetangga atau kerabat yang membutuhkan juga dilakukan pada kegiatan bedah rumah ini.

Bagi warga yang memiliki peralatan juga umumnya secara spontan membawa sendiri peralatannya dan mengggunakannya sendiri untuk bekerja atau dipinjamkan untuk digunakan siapa saja. Di antara warga yang berpartisipasi, Amsir (34 tahun) mengatakan: "Saya selalu berpartisipasi harta benda seperti meminjamkan alat-alat kerja seperti skop, slang, gergaji, dan alat-alat lainnya, sampai-sampai alat yang saya pinjamkan itu ada yang tidak kembali lagi”.

Umumnya yang berpartisipasi peralatan ini karena ingin atau harapan pelaksanaan ini berjalan lancar dan cepat selesai. Bantuan peralatan sangat penting karena jumlah rumah yang dibedah sebanyak 20 unit dalam satu periode sehingga membutuhkan pula banyak peralatan kerja. Dengan kesadaran warga yang secara serempak menggunakan atau meminjamkan peralatan sehingga sangat membantu dalam kelancaran pengerjaan atau penyelesaian rumah yang dibangun atau direnovasi.

Warga juga tidak hanya membantu peralatan kerja melainkan membantu bahan- bahan yang bisa digunakan sebagaimana dikemukakan salah seorang warga, La Ode Abdul Kadir (21 tahun) yang mengatakan: "Partisipasi harta benda yang saya berikan berupa bahan-bahan bangunan berupa kayu dan batu untuk pembangunan bedah rumah".

Bahan-bahan yang diberikan tersebut secara sukarela atau cuma-cuma. Batu digunakan untuk fondasi rumah. Kayu untuk berbagai bahan bangunan rumah, seperti untuk rangka atap.

\section{Partisipasi Masyarakat dalam Bentuk Dana}

Mayoritas warga adalah petani ladang dengan kondisi ekonomi lemah namun secara sukarela ikut menyumbang untuk turut membantu renovasi rumah warga. Jumlah uang yang disumbangkan sesuai kemampuan mulai dari Rp 20.000 hingga ratusan ribu rupiah namun karena jumlah yang menyumbang hampir semua warga sehingga cukup lumayan membantu untuk pembelian bahan yang diperlukan, seperti kayu balok, papan, dan semen dan sebagainya.

Mereka mengetahui bahwa dalam program bantuan bedah rumah ini disediakan bantuan dari pemerintah namun dianggap tidak cukup untuk kebutuhan renovasi tersebut, sebagaimana penuturan seorang warga, La Inda (48 tahun) mengatakan: "Saya meyumbangkan uang, namun dengan jumlah yang sedikit, karena bantuan dana dari pemerintah tidak cukup untuk membiayai pembangunan rumah sampai selesai".

Berdasarkan pernyataan warga tersebut di atas menunjukkan bahwa partisipasi warga dalam bentuk dana sangat penting dalam program renovasi rumah karena tanpa bantuan warga maka tidak bisa merenovasi rumah sampai tuntas atau minimal dana bantuan warga mempercepat penyelesaian renovasi rumah warga. Bantuan warga juga diharapkan menjadi stimulant untuk mendapatkan jatah dari 
program bedah rumah.

\section{Partisipasi Masyarakat dalam Bentuk Keterampilan}

Sudah kebiasaan masyarakat desa ini bekerja apa saja untuk mendapatkan uang, seperti menjadi buruh bangunan, membantu tukang kayu, menjadi buruh harian proyek pembangunan dan sebagainya. Dari pekerjaan ini kemudian mereka memiliki pengalaman dan keterampilan, misalnya keterampilan sebagai tukang batu dan tukang kayu.

Beberapa warga yang memiliki keterampilan ikut membantu dalam kerja bakti warga membangun atau memperbaiki rumah warga secara sukarela. Mereka datang dan ikut bekerja sesuai keterampilan atas inisiatif sendiri, misalnya menjadi tukang batu yang membuat fodasi rumah, tukang kayu membuat rangka untuk atap, kuseng pintu dan jendela. Kerelaan mereka membantu sesuai keterampilan masingmasing sebagaimana disampaikan oleh salah seorang dari mereka, Amsir (34 tahun) mengatakan: "Karena saya tukang batu, jadi keterampilan yang saya berikan yaitu dengan membangun fondasi rumah, dan saya sering disuruh untuk gambar fondasi rumah yang akan dibangun", dan La Jiu (60 tahun) mengatakan: "Sumbangan keterampilan, karena saya sebagai tukang kayu, saya meyumbangkan keterampilan saya pada pembuatan rangka atap rumah saja".

Warga lainya yang tidak memiliki keterampilan seperti itu biasanya ikut membantu, misalnya mengangkat batu, pasir, balok dan papan serta membantu memasang batu dan rangka kayu. Warga yang membantu tukang batu dan tukang kayu ini mendampingi para tukang ini sampai pekerjaan selesai. Mereka mengaku tidak tega meninggalkan temannya yang memiliki keterampilan yang telah rela bekerja tanpa upah. Dengan demikian, kehadiran warga yang memiliki keterampilan ini yang tanpa upah turut memberi sugesti atau motivasi bagi warga untuk ikut bekerja selain penghematan biaya pembangunan rumah.

Fakto-Faktor yang Mempengaruhi Partisipasi Masyarakat dalam Program Bedah Rumah

Menurut Dorodjatin (Slamet, 2003), ada beberapa faktor yang dapat mendukung dan menghambat partisipasi masyarakat dalam dalam suatu program. Timbulnya partisipasi merupakan ekspresi perilaku manusia untuk melakukan suatu tindakan, dimana suatu perwujudan dari perilaku tersebut didorong oleh dua faktor utama, yaitu: (1) kemauan dan (2) kesempatan bagi masyarakat untuk berpartisipasi. Selain itu ada juga faktor penghambat partisipasi masyarakat dalam pembangunan, yaitu: (1) tingkat pendidikan rendah dan (2) rasa tidak percaya diri. Rendahya tingkat pendidikan sangat berpengaruh terutama dalam memberikan pandangan-pandangan atau masukan tentang program bedah rumah. Terutama dalam pertemuan atau musyawarah, khususnya pada tahap persiapan, yang cukup barpartisipasi menyampaikan pendapatnya hanya yang mempunyai tingkat pendidikan minimal tingkat SLTA.

Dalam tahap pelaksanaan, faktor pendidikan tidak terlalu siginifikan berpengaruh karena pada tahap ini terutama diperlukan kemampuan fisik dan keterampilan. Keterampilan sendiri, seperti tukang batu dan tukang kayu umumnya keterampilan mereka karena pengalaman ikut bersama atau membantu tukang yang sudah terampil. Apalagi kemampuan fisik, justru yang banyak membantu dari tingkat pendidikan rendah karena umumnya yang tingkat pendidikan yang rendah ini banyak beraktifivitas fisik, seperti kerja bertani dan kerja buruh.

Pada tahap evaluasi, tingkat pendidikan juga cukup signifikan berpengaruh. Penilaian dalam setiap tahap atau dalam proses program bedah rumah ini diperlukan kemampuan nalar dan perhitungan. Mereka 
yang menilai berbagai tahap dan memberi argument adalah mereka yang tingkat pendidikannya minimal tingkat SLTA.

Pengaruh pendidikan ini dalam partisipasi program bedah rumah sebagaimana dikatakan oleh La Ode Rudi (34 tahun): "Tentunya masyarakat yang tidak berpendidikan susah untuk memberikan partisipasinya, apalagi partisipasi ide atau gagasan, kalaupun mereka sedang berada di tempat kerja mereka lebih banyak menonton dan mendengar karena mereka tidak tahu apa-apa soal pembangunan rumah" (Wawancara, 10 September 2019).

Demikian pula disampaikan oleh Beni (20 tahun) yang mengatakan: "Saya tidak ikut bekerja dalam pelaksanaan program bedah rumah karena saya tidak sekolah, makanya saya tidak tahu apa-apa tentang ukuran-ukuran fondasi, kayu dan ukuran lainnya, palingan saya hanya bisa bantu dengan mengangkat bahan saja" (Wawancara, 17 September 2019).

Rasa tidak percaya diri membuat seseorang tidak yakin dengan kemampuannya sehingga sulit untuk menggali dan memunculkan potensi yang ada pada dirinya. Hal ini membuat orang menjadi sulit berkembang karena ia sendiri tidak mau berkembang sesuai potensi yang dimilikinya. Tidak berpartisipasinya sebagian warga dalam program bedah rumah ini karena rasa tidak percaya diri, sebagaimana dikemukakan oleh salah seorang warga, La Ege (39 tahun) yang mengatakan bahwa : "saya lihat masyarakat dalam desa kita ini banyak yang pintar tukang, seperti tukang kayu, tapi mereka sembunyikan itu, itu karena mereka takut salah di depan masyarakat lain" (Wawancara, Sepetmber 2019). Hal senada sebagaimana ungkapan La Rudi (33 tahun) yang mengatakan bahwa: "Saya tidak percaya diri, padahal sebenarnya saya bisa susun batu fondasi, tapi saya ragu jangan sampai dibilang sok pintar sama warga" (Wawancara, 20 September 2019).
Berdasarkan hasil wawancara yang dikemukakan oleh informan di atas dapat disimpulkan bahwa masyarakat Desa Poaroha yang kurang percaya diri terhadap kemampuannya sendiri, berpikir jangan sampai terjadi kegagalan dalam bekerja sehingga mereka takut untuk ikut serta dalam kegiatan pembangunan bedah rumah di desa ini.

Rasa tidak percaya diri juga dapat diartikan sebagai penyakit mental individu dalam lingkungan sosial, untuk itu dengan rasa tidak percaya diri ini dapat membuat masyarakat untuk tidak berpartisipasi karena dirinya yang telah diselimuti keraguan dalam diri saat berhadapan dengan orang lain di luar keluarganya. Mereka yang tidak percaya diri kemudian tidak berpartisipasi dalam kegiatan atau program bedah rumah ini sesungguhnya mempunyai keinginan berpartisipasi.

\section{Fakor Pendorong Partisipasi Masyarakat dalam Program Bedah Rumah}

Sebagaimana telah dikemukakan di atas bahwa menurut Dorodjatun, faktor pendorong partisipasi masyarakat adalah kemauan dan kesempatan masyarakat untuk berpartisipasi, maka berikut ini dikemukakan aspek-aspek kemauan dan kesempatan masyarakat sebagai faktor pendorong berpartisipasi dalam program bedah rumah.

\section{Kemauan}

Kemauan atau willingness mengandung arti do something fairly enthusiastically and because they want to do it rather than because they are forced to do it (Angeli, 2015). Kemauan mengandung makna kerelaan untuk melakukan dengan antusias tanpa paksaan atau tekanan apapun. Jadi kemauan adalah dorongan dari dalam secara sadar, berdasarkan pertimbangan pikir dan perasaan sendiri serta seluruh peribadi seseorang yang menimbulkan kegiatan atau tindakan yang terarah pada tercapainya tujuan tertentu. Dorongan dari dalam diri seseorang ini karena telah menjadi nilai yang sudah ter- 
tanam melalui proses internalisasi, seperti nilai gotong royong $\mathrm{dsb}$.

Partisipasi masyarakat dalam program rumah di Desa Poaroha ini umumnya atas kemauan sendiri atau atas kesadaran sendiri. Kesadaran sendiri karena memang telah tertanam nilai gotong royong sejak lama. Atas kemauan sendiri dari masyarakat sebagaimana diungkapkan salah seorang warga, La Ode Rudi (34 tahun) yang mengatakan: "Saya lihat dalam kegiatan pelaksanaan program bedah rumah bahwa banyak masyarakat yang datang membantu tanpa ada panggilan dari pemilik rumah, intinya mereka bekerja atas kemauan mereka sendiri tanpa ada yang paksa mereka" (Wawancara, 10 September 2019). Begitu juga diungkapkan La Ode Abdul Kadir: "Saya ikut bekerja atas kemauan saya, tanpa ada ajakan siapapun ataupun dipaksa, dan saya bekerja tidak ada keluhan sama sekali karena ini semua atas kemauan saya" (Wawancara, 13 September 2019).

Partisipasi berdasarkan kemauan sendiri merupakan salah satu energy sosial yang dapat mempercepat proses pelaksanaan program bedah rumah yang lebih efisien. Karena atas kemauan sendiri ini sendiri sehingga mereka bekerja hampir tak kenal lelah dalam memberikan bantuan tenaga bahkan memberikan batuan materi sesuai kemampuannya.

\section{Kesempatan}

Kesempatan dalam hal ini ada kesempatan dan diberi kesempatan merupakan salah satu faktor pendorong masyarakat desa ini untuk berpartisipasi dalam program bedah rumah warga. Sebagian besar mereka adalah petani yang memiliki waktu luang untuk ikut dalam kegiatan yang dilakukan warga atau pemerintah. Keinginannya untuk berpartisipasi karena juga diberi kesempatan sehingga dapat dan mau meluangkan waktunya untuk ikut serta dalam program bedah rumah ini. Dengan adanya kesempatan dan diberi kesempatan kepada warga ini untuk turut dalam program dan pekerjaan perbaikan rumah warga sehingga program ini dapat terlaksana sesuai waktu yang direncanakan karena mereka hadir secara kompak.

Pengaruh adanya kesempatan dan diberi kesempatan sehingga warga berpartisipasi dalam program bedah rumah masyarakat setempat sebagaimana diungkapkan salah seorang warga, La Ode Rudi (34 tahun) yang mengatakan: "Saya lihat masyarakat kita di Desa Poaroha ini selalu ikut serta dalam setiap program, itu dikarenakan mereka memiliki kesempatan waktu luang dan diberi kesempatan untuk saling membatu, dan saya juga peribadi selalu menyempatkan diri untuk ikut bantu dalam pembangunan bedah rumah masyarakat" (Wawancara, 10 September 2019). Warga lain, La Anda (37 tahun) juga mengatakan: "Dalam pembangunan bedah rumah ini saya melihat warga lainnya datang ikut bekerja dalam pembangunan rumah, juga saya ikut bekerja dalam proses pekerjaan itu karena kesempatan waktu yang saya miliki dan bisa dilibatkan ikut bekerja" (Wawancara, 18 September 2019).

Kesempatan yang diberikan kepada warga dimaksudkan agar warga ini bisa menggunakan waktunya untuk ikut serta dalam pembangunan rumah warga, sebagaimana dikemukakan salah seorang pengelola program bedah rumah ini, La Ege (39 tahun) yang mengatakan "Saya sengaja program bedah rumah ini saya serahkan pada warga untuk mengelolanya atau membangunnya, karena dengan begitu masyarakat juga bisa melihat dan ikut langsung dalam pembangunan bedah rumah ini" (Wawancara, 11 September 2019).

Dengan demikian, faktor kesempatan dalam hal ini adanya kesempatan atau waktu yang diluangkan warga dan jika warga diberi kesempatan untuk berpartisipasi sangat besar pengaruhnya terhadap motivasi warga untuk berpartisipasi dalam program bedah rumah ini. Hal ini tidak sebagaimana hasil penelitian Fikra Sutan 
Purnama bahwa sekalipun masyarakat yang berada di Kota Tangerang diberi kesempatan mereka tidak mau melakukannya (2016).

\section{PENUTUP}

Bentuk-bentuk partisipasi masyarakat dalam Program Bedah Rumah dengan model partisipatif meliputi keterlibatan masyarakat menyumbangkan pikiran terutama yang memiliki pengetahuan dan keterampilan yang terkait program, tenaga fisik dengan bekerja secara maksimal, keterampilan pertukangan di mana tanpa diminta ikut bekerja sesuai keterampilan masing-masing, bahan bangunan terutama yang memiliki sisa bahan bangunan disumbangkan dan peralatan yang diperlukan meminjamkan untuk digunakan serta dana sesuai kemampuan masing-masing.

Faktor-faktor yang mempengaruhi sehingga mereka berpartisipasi tersebut terutama karena masyarakat ini dipercayakan melaksanakan program untuk kepentingan mereka sendiri yang membuat mereka seakan-akan tak kenal lelah dan menyumbangkan yang mereka miliki. Kesempatan yang diberikan untuk melaksanakan sendiri program ini menjadi social-energy dalam berpartisipasi sehingga sekalipun telah membantu bekerja dan meminjamkan peralatan, mereka tetap menyumbang bahan bangunan yang dimiliki serta dana sesuai kemampuannya masing-masing. Berbagai kepemilikan, kepemilikan sisa bahan bangunan, keterampilan pertukangan ini sebagai faktor berpengaruh setelah diberi kepercayaan dan kesempatan. Faktor kemauan terutama yang didasari nilai gotongroyong masyarakat desa ini merupakan faktor yang juga cukup berpengaruh terhadap partisipasi masyarakat dalam program bedah rumah ini.

\section{DAFTAR PUSTAKA}

Angeli, Michele. (2015). Willing to define willingness: The (Almost) Final Word on SEP-Based Injuctions in Light of Samsung \& Motorola. Journal of European Law \& Practce, Vo. 6, Issu 4, hal. 221241.

Astuti, Afifah Dwi. 2013). Partisipasi Masyarakat dalam Pembangunan Masyarakat Desa melalui Usaha Mikro Pegolahan Susu Kambing Etawa di Tlogoguwo, Kaligesing, Purworejo, Jawa Tengah. Skripsi. Yogyakarta: Fakultas Ilmu Pendidikan Universitas Negeri Yogyakarta.

Mikkelsen, Britha. (1999). Merode Penelitian Partisipatoris dan Upaya-Upaya Pemberdayaan: Sebuah Buku Pegangan bagi Para Praktisi Lapangan. Jakarta. Yayasan Obor Indonesia.

Nababan, Labuan dan Sinambela, Lamtiur. (2018). Sistem Pendukung Keputusan Penentuan Kelayakan Bedah Rumah Keluarga Miskin Menggunakan Metode Moora. Jurnal Teknik Informatika Kaputama (JTIK), Vol. 2, No. 2, ISSN: 2548-9704, hal.20-27.

Pramita, Asta Lugra dan Murjana Yasa, I Gusti Wayan. (2015). Peranan Dana Bantuan Sosial terhadap Kualitas Rumah Masyarakat Miskin melalui Program Bedah Rumah di Kabupaten Buleleng. EJurnal Ekonomi dan Bisnis Universitas Udayana, 4.02, hal.106-124.

Sastropoetro, R.Ass. (1998). Partisipasi Komunikasi, Persuasi dan Disiplin Dalam Pembangunan. Bandung: Alumni

Slamet. (2003). Pembangunan Masyarakat Berwawasan Partisipasi. Surakarta: Sebelas Maret Universitas Press. 
Supriana, I Wayan dan IWK Teja Sukmana. (2016). Sistem Pendukung Keputusan Penentuan Penerima Bantuan Bedah Rumah di Desa Senganan. Jurnal Teknologi Informasi dan Komputer, Volume 2, Nomor 2, hal.245-257.

Suroso, Hadi dan Abdul Hakim, Irwan Nur. (2014). Faktor-faktor yang Mempengaruhi Partisipasi Masyarakat dalam Perencanaan Pembangunan di Desa Banjaran Kecamatan Driyorejo Kabupaten Gresik. Wacana, Vol. 17, No.1, hal. 7-16.

Sutrisno, Aidin. (2014). Problematika Program Bedah Rumah bagi Masyarakat Penerima Bantuan (Study Kasus pada Penerima Program Bedah Rumah di Kelurahan Pematang Gubernur Kota Bengkulu. Skripsi. Bengkulu: Fakultas Ilmu Sosial dan Ilmu Politik Universitas Bengkulu.

Syahyuti. (2006). Konsep Penting Dalam Pembangunan Pedesaan Dan Pertanian: Penjelasan Tentang Konsep Istilah. Teori dan Indikator Serta Variabel. Bandung: Bina Arena Pariwara.

Tondo, Simon. (2017). Implementasi Kebijakan Pengentasan Kemiskinan Melalui Program Bedah Rumah (Studi Kasus di Kecamatan Loloda Utara Kabupaten Halmahera Utara, Maluku Utara). Jurnal Ilmu Adminstrasi Negara-ASIAN, Volume 5 Nomor 2, hal. 63-77.

Warjio. (2014). Partisipasi Masyarakat dalam Perencanaan Pembangunan (Studi Kasus pada

Kecamatan Sidikalang Kabupaten Dairi). Jurnal Adminstrasi Publik (JAP), Vol. 2 No. 2, hal 116-144.
Yushy, Yossyafra dan Noer, Melida. (2016). Evaluasi Pelaksanaan Program Bedah Rumah di Kota Padang. http://pasca.unand.ac.id/id/prosidin g-seminar-nasional-perencanaanpembangunan-inklusif-desa-kota. Diakses 8 Februari 2020.

Peraturan Menteri Pekerjaan Umum dan Perumahan Rakyat RI Nomor 07/PRT/M/2018. 